\title{
Prenatal diagnosis of bullous ichthyosiform erythroderma: detection of tonofilament clumps in fetal epidermal and amniotic fluid cells
}

\author{
R A J EADY, D B GUNNER, L DORIA LAMBA CARBONE*, \\ F DAGNA BRICARELLI*, C M GOSDEN†, AND C H RODECK \\ From the Department of Electron Microscopy and Cell Pathology, Institute of Dermatology, Homerton \\ Grove, London; *Centro Regionale di Genetica Umana, Ospedali Galliera, Genoa, Italy; †MRC \\ Clinical and Population Cytogenetics Unit, Western General Hospital, Edinburgh; and \\ $\ddagger$ Harris Birthright Research Centre for Fetal Medicine, King’s College Hospital Medical School, London.
}

SUMMARY The prenatal diagnosis of bullous ichthyosiform erythroderma (BIE) has been achieved at 20 weeks' gestation by electron microscopic identification of a pathognomonic cytoskeletal abnormality within fetal epidermal cells obtained by fetoscopic skin biopsy. The same abnormality was also observed in skin derived amniotic fluid cells. The question whether amniocentesis might be used instead of fetoscopy for future prenatal detection of BIE is discussed.

Bullous ichthyosiform erythroderma (BIE) is one of the more severe types of congenital ichthyosis ${ }^{1-4}$ and is transmitted as an autosomal dominant trait. Its incidence has not been established although it is presumed to be very low. Clinically, BIE presents at birth or soon afterwards with widespread erythroderma, blistering, and scaling. Blistering tends to improve with age. Warty thickening of the flexural skin usually appears by the third or fourth year and persists into adult life. There is, in addition, hyperkeratosis of the palms and soles. Life expectancy is usually normal although the disease can be severely incapacitating. Death, often associated with severe infection, may occur in infancy.

The diagnosis of BIE depends on the detection of highly characteristic tonofilament clumps in the epidermal cells, associated with intraepidermal vacuolation and hyperkeratosis. ${ }^{56}$ The condition has been diagnosed prenatally by light and electron microscopy of fetal skin biopsy samples obtained at 19 or 20 weeks of gestation. ${ }^{78}$ In a retrospective study, Holbrook et al' ${ }^{\prime}$ detected the characteristic tonofilament aggregates within the amniotic fluid cells (in addition to the fetal epidermis) associated with two affected pregnancies and postulated that prenatal diagnosis of BIE might be possible by morphological analysis of amniotic fluid cells with-

Received for publication 19 November 1984

Accepted for publication 11 January 1985 out recourse to fetoscopy and fetal skin biopsy. We have succeeded in diagnosing BIE prenatally by detecting tonofilament clumps in both fetal skin and amniotic fluid cells at 20 weeks' gestation. Our findings are reported here.

\section{Case report}

The patient was a 37 year old woman who had suffered from BIE since birth. She had many of the typical features of the disease, including widespread erythema, hyperkeratosis, and scaling. The hyperkeratosis was accentuated in the major flexures and was particularly severe on the hands and feet, affecting both ventral and dorsal surfaces. When she was young blistering was a constant problem, but as she became older it tended to occur mainly in winter.

A skin biopsy specimen taken from a hyperkeratotic area on the patient's right hip showed characteristic histological changes of BIE, namely hyperkeratosis and vacuolation of the epidermis above the basal layer, associated with darkly staining intracellular granules or inclusions, many of which were larger than normal keratohyalin granules (fig 1).

FAMILY HISTORY

The patient's parents were not consanguineous and no other family member was affected. There was no 


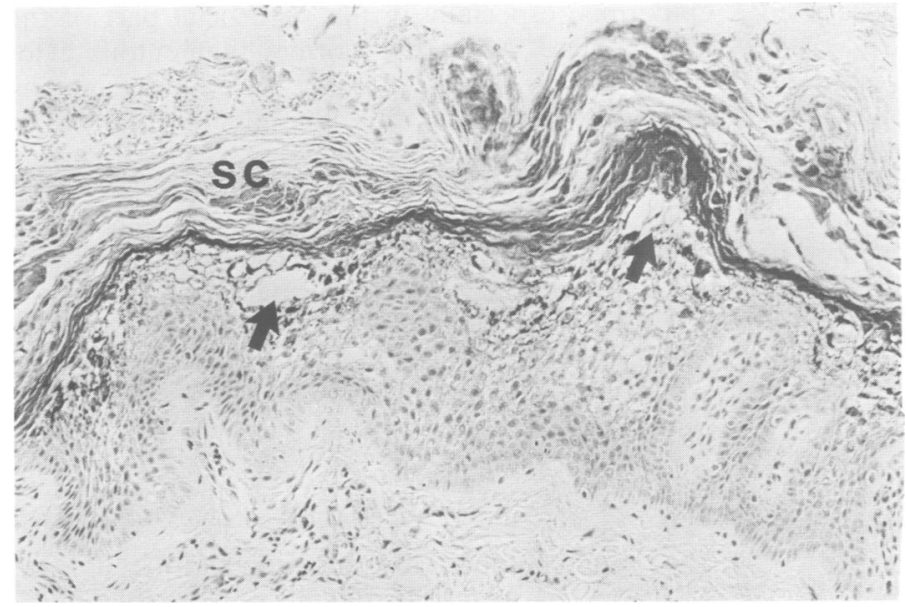

FIG 1 Photomicrograph of proband's skin. Note thickening of the epidermis, especially affecting the stratum corneum (sc) and vacuolation (arrows) of the stratum granulosum which contains large granules. (Haematoxylin and eosin. Original magnification $\times 140$.)

history of ichthyosis or blistering in her husband's family.

In 1978, her first child, a boy, was born with erythema and widespread blistering (fig 2). He died at 6 days of age with severe generalised candidiasis. Skin biopsy showed changes of BIE similar to those present in the mother's skin. In 1983, she had a spontaneous abortion at eight weeks' gestation. Later in the same year, she became pregnant again and, knowing that there was a $50 \%$ chance of having another affected child, sought prenatal diagnosis.

\section{Investigations}

FETOSCOPY AND FETAL SKIN BIOPSY

Using the procedure we have previously described, ${ }^{10-12}$ fetoscopy and fetal skin biopsy were carried out under real time ultrasound guidance at

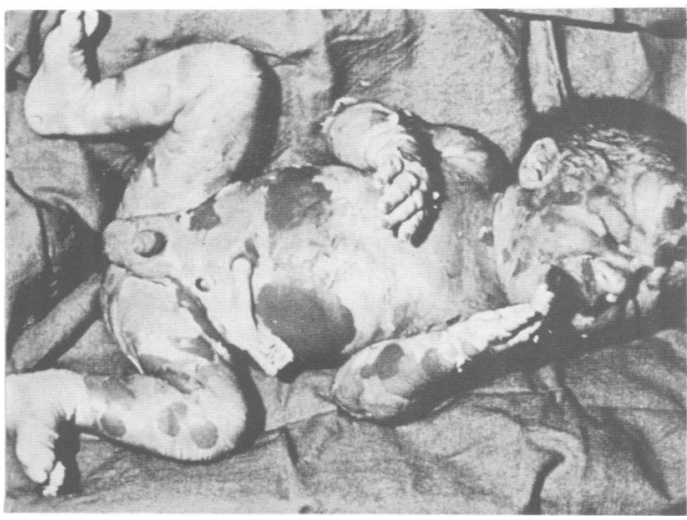

FIG 2 Proband's first child who died soon after birth with widespread blistering. (Reproduced with permission from Prospettive in Pediatria, 1981.) an estimated gestational age of 20 weeks. The fetal biparietal diameter was $51 \mathrm{~mm}$ and the femur length $32 \mathrm{~mm}$, confirming the gestational age of 20 weeks. The amniotic fluid was cloudy and the fetal scalp was scaly, giving the appearance of 'dandruff'. No blisters or erosions were seen. One skin biopsy was taken from the left hip. It was not possible to obtain further skin samples because the patient began to vomit and the fetoscope had to be withdrawn. The fetal skin sample was immediately immersed in fixative and processed for light and electron microscopy using a rapid technique. ${ }^{13}$ Semithin sections of the plastic embedded fetal skin were stained with basic fuchsin and methylene blue or with methylene blue and azure II for light microscopy. Ultrathin sections were stained with uranyl acetate and lead citrate and examined in a JEOL $100 \mathrm{CX}$ transmission electron microscope.

AMNIOTIC FLUID CELL ANALYSIS

During fetoscopy, amniotic fluid was withdrawn for morphological and cytogenetic studies.

\section{Morphological studies}

A total of $10 \mathrm{ml}$ amniotic fluid was centrifuged at $1500 \mathrm{rpm}$ for five minutes. The resulting pellet of cells was resuspended in $0 \cdot 1 \mathrm{~mol} / \mathrm{l}$ cacodylate buffer with $7 \%$ bovine serum albumin. After a second centrifugation, the pellet was fixed for one hour in half-strength Karnovsky fixative ${ }^{14}$ in $0.1 \mathrm{~mol} / \mathrm{l}$ cacodylate buffer containing $5 \%$ sucrose and $0.05 \%$ $\mathrm{CaCl}_{2}$. After several washes in buffer, the pellet was postfixed in $1 \%$ osmium tetroxide in distilled water for one hour on ice. After dehydration in graded alcohol, the cells were embedded in TAAB resin. Sections were prepared for light and electron 
microscopy using similar techniques to those used for fetal skin samples (see above).

Total cell counts, viable cell counts, and estimates of numbers and origins of red blood cells in the amniotic fluid were made after vital staining of the cells with trypan blue. ${ }^{15}$ 16 Size class analysis was also carried out. Scanning electron microscopy preparations were made according to the method of Rodeck et al. ${ }^{10}$ Cells were layered onto alcian blue treated coverslips and examined in a Cambridge S180 scanning electron microscope.

\section{Chromosome studies}

Using the methods of Gosden et al, ${ }^{17}$ chromosome studies were carried out on cultured amniotic fluid cells because of the risks of autosomal trisomy with the advanced maternal age.

\section{Results}

SKIN MICROSCOPY

The single skin specimen was sufficiently large and well preserved for detailed morphological examination. The microanatomy of the epidermis was grossly altered: there was widespread vacuolation associated with dense cytoplasmic inclusions affecting all cell layers between the stratum basale and periderm (fig 3). The epidermal vacuolation was more marked than might be expected (probably as a result of biopsy artefact) in fetoscopic samples of normal fetal skin of similar gestational age (see below).

Electron microscopy revealed a variable degree of intracellular oedema and cytolysis within the epidermis, especially in the superficial part of the intermediate layer. The normal filamentous cytoskeleton was grossly altered. Instead of coursing through the cytoplasm, the tonofilaments tended to aggregate in tight intracellular clumps with relatively regular borders (fig 4). Desmosomes appeared generally normal. The clumps were not detected in either periderm or basal cells. The ultrastructure of the periderm appeared normal for 20 weeks' gestation. ${ }^{18}$ There were focal zones of regressing periderm with early corneocyte formation. In these areas, small keratohyalin granules were also evident.

AMNIOTIC FLUID CELLS

Cell counts

The total number of amniotic fluid cells was $71400 / \mathrm{ml}$ of which $16700 / \mathrm{ml}$ were viable $(23 \%$ viability). Fewer than $1 \%$ of the viable cells were $\mathbb{D}$ rapidly adherent to glass in the short term (20 hour) cultures. It was, however, interesting to note that the only adherent cells were those in the clumps which were very similar in appearance to those seen in the scanning electron microscope (see below).

Light and transmission electron microscopy

Several semithin sections taken from different blocks of the same pellet were examined by light microscopy. About $10 \%$ of cells contained intracytoplasmic dense inclusions. Many cells with the inclusions were still attached to periderm derived cells (fig 5). Electron microscopy revealed that the inclusions were tonofilament aggregates similar to those seen in fetal epidermis (fig 6).

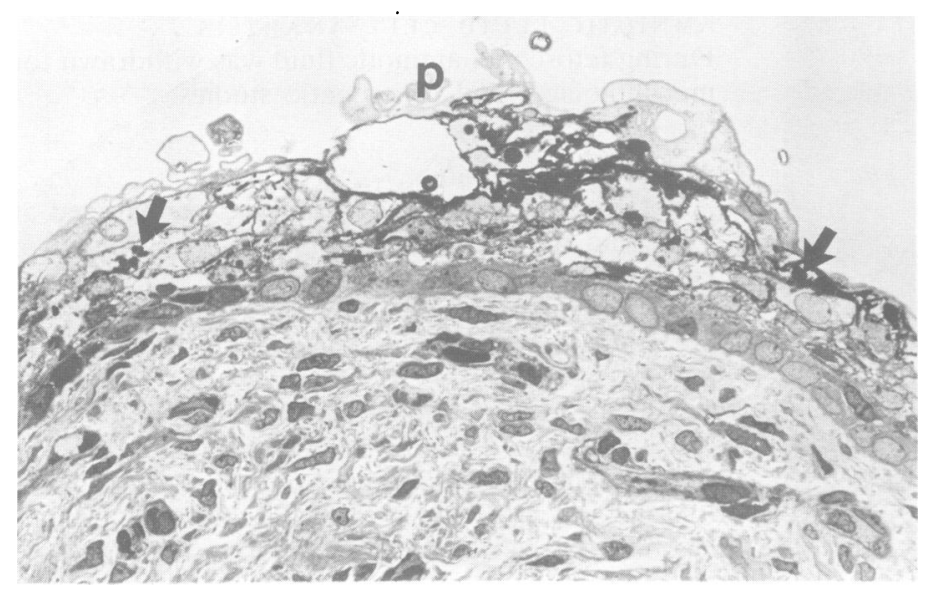

FIG 3 Photomicrograph of fetoscopic skin sample showing gross disruption, especially vacuolation, of the fetal epidermis at 20 weeks' gestation. Dense cytoplasmic inclusions (arrows) are evident in all epidermal cell layers, except the periderm ( $p$ ) and basal layer. (Basic fuchsin and methylene blue. Original magnification $\times 710$.) 


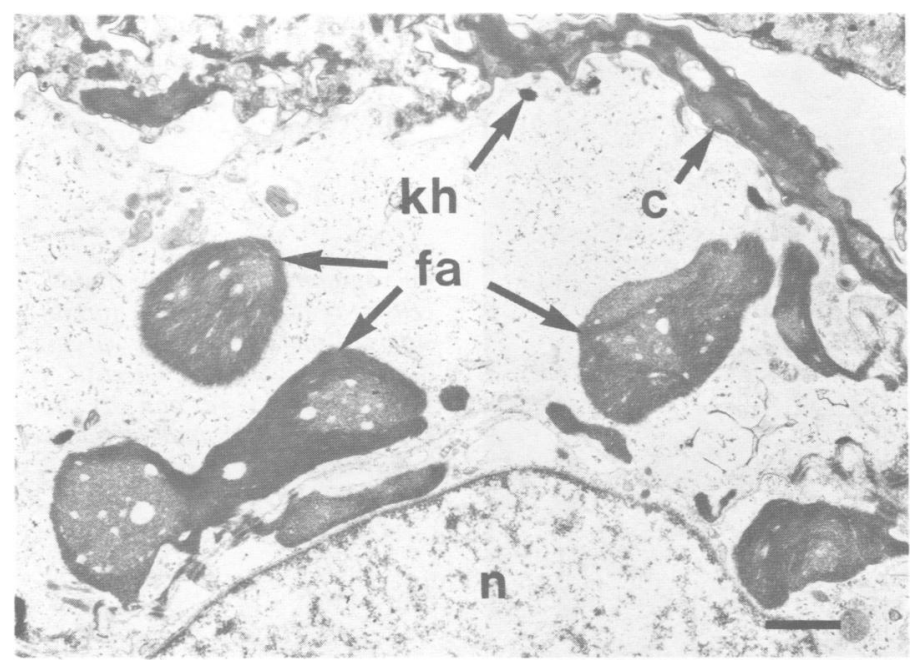

FIG 4 Electron micrograph showing numerous tonofilament aggregates $(\mathrm{fa})$ in the fetal epidermis. Early keratohyalin ( $k h)$ and corneocyte (c) formation is evident. $n=$ nucleus. Bar $=1 \mu \mathrm{m}$.

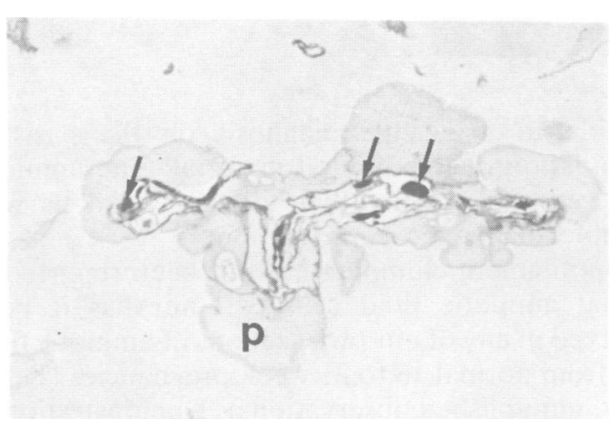

FIG 5 Photomicrograph of 1 um plastic embedded section showing a clump of amniotic fluid cells. Darkly staining granules (arrows) can be seen in cells that are attached to periderm derived cells $(p)$. (Methylene blue and azure II. Original magnification $\times 280$.)
Scanning electron microscopy

Normally, individual cells are seen (fig $7 \mathrm{a}$ and b), each characteristic of the fetal cell surface from which the cells have been shed (for example, fetal skin, trophoblast, respiratory tract). In this case, many cellular clumps were observed containing cells with variable surface characteristics (fig $7 c$ and d).

\section{CHROMOSOME ANALYSIS}

Analysis of the cultured fetal cells showed them to have a 46,XX apparently normal female karyotype. The fetal chromosomal fluorescence heteromorphisms were compared with those of the mother. These confirmed that the fetal cells were distinct from those of the mother and that no maternal contamination was present.

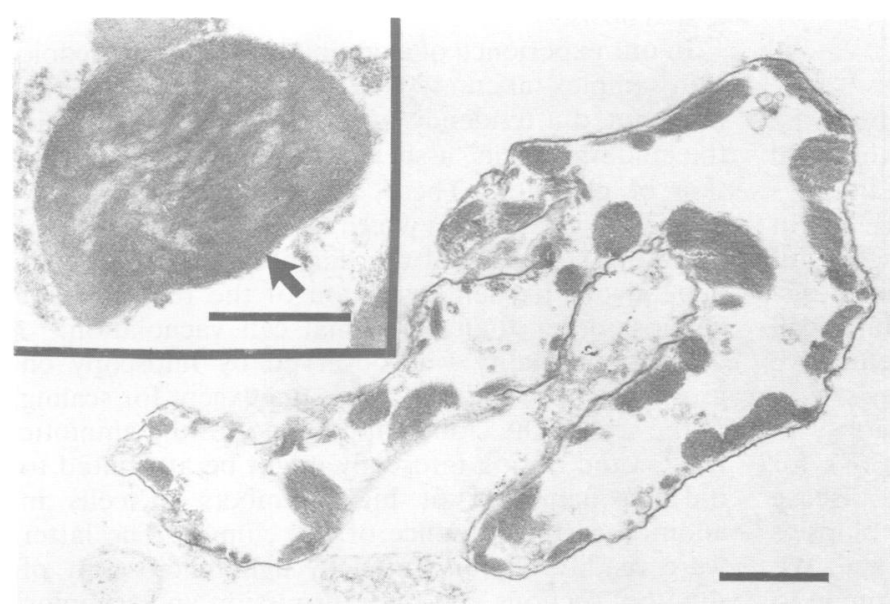

FIG 6 Electron micrograph of an amniotic fluid cell containing numerous filament aggregates. Bar $=1 \mu \mathrm{m}$. Inset shows detail of an aggregate with characteristic banding (arrow) where filaments are aligned. Bar $=1 \mu \mathrm{m}$. 


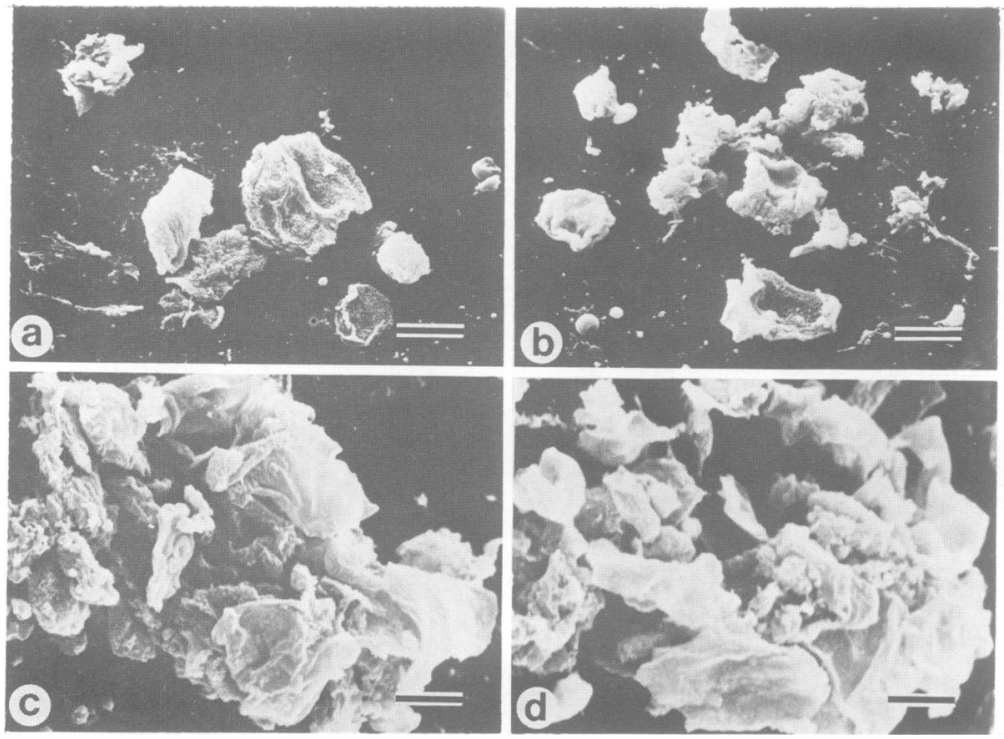

FIG 7 Scanning electron micrographs of amniotic fluid cells. (a) and (b) show normal singly dispersed cells of varying dimensions with characteristic surface features. (c) and (d) show clumps of cells found in bullous ichthyosiform erythroderma. Bars $=15 \mu \mathrm{m}$.
TERMINATION OF PREGNANCY

The fetus was aborted at 21 weeks' gestation by intra-amniotic prostaglandin injection. At delivery the skin looked generally normal with the exception of a few small superficial erosions. There were no blisters. An hour after delivery, the skin appeared very dry and wrinkled, especially on the elbows, knees, and ankles. The skin on the palms and soles was abnormally thick and scaly. A skin sample taken adjacent to an eroded area showed characteristic histological features of epidermolytic hyperkeratosis. Electron microscopy demonstrated clumping of tonofilaments in the epidermis which was less marked compared with that seen in the fetoscopic skin biopsy.

\section{Discussion}

In this study there was no difficulty in identifying the diagnostic tonofilament clumps in both fetal epidermis and amniotic fluid cells. Our findings therefore strengthen the proposal ${ }^{9}$ that BIE might be detected in utero by electron microscopy of amniotic fluid cells obtained by amniocentesis. However, we feel that the amniotic fluid cell abnormality needs further confirmation before we could consider recommending amniocentesis as a preferable alternative to fetoscopic skin biopsy in the prenatal examination of pregnancies at risk for BIE. The patchy clinical expression of the disease indicates that, where possible, fetal skin biopsies from several different sites should be examined. We could obtain only one sample and were fortunate to be able to make the diagnosis on the basis of examination of this limited material. The amniotic fluid cell abnormality therefore provided us with valuable diagnostic confirmation.

Tonofilament clumping has not been reported in normal amniotic fluid cells, ${ }^{19}{ }^{20}$ nor has it been observed in any of our own sections of amniotic fluid cells from normal 18 to 21 week pregnancies (R A J Eady, unpublished observations). Demonstration of the tonofilament abnormality by indirect immunofluorescence using monoclonal antikeratin antibodies might prove a useful alternative or addition to transmission electron microscopy in the future. Preliminary results with this technique in the present case $^{21}$ were not sufficiently clear cut for the basis of a diagnosis.

In our experience of examining over 60 fetoscopic skin samples taken at 18 to 21 weeks' gestation, we have noted a tendency for vacuoles to form within the epidermal cells, associated with apparent extraction of glycogen. These changes, therefore, may mimic the vacuolation which also occurs in BIE. We therefore suggest that the diagnosis of BIE should depend on the demonstration of the tonofilament clumps rather than epidermal cell vacuolation.

No abnormality was observed by fetoscopy on gross appearance of the fetal skin except for scaling of the scalp. The cloudy appearance of the amniotic fluid noted during fetoscopy might be attributed to the desquamation of high numbers of cells in addition to the presence of cell clumps. The latter were readily demonstrated by light microscopy of semithin sections and by transmission and scanning 
electron microscopy. The total amniotic fluid cell numbers are very close to the upper limit for normality, while the viable cell numbers and proportion of viable cells are relatively low ${ }^{22}$ indicating that the cell dynamics seem disturbed in this case. An increased production of amniotic fluid cells by skin might result from excessive epidermal cell proliferation and rapid transepidermal cell transit, as demonstrated in adult patients with BIE. ${ }^{23}$

It is possible to diagnose other forms of ichthyosis before birth. Both harlequin ichthyosis ${ }^{24}$ and Sjögren-Larsson syndrome ${ }^{25}$ have been detected by microscopy of fetoscopic skin biopsies. The diagnosis of $\mathrm{X}$ linked ichthyosis has been achieved by biochemical analysis of amniotic fluid. ${ }^{26}$

This work was supported by a grant (to RAJE) from the Herbert E Dunhill Trust.

\section{References}

' Brocq L. Erythrodermic congenitale ichthyosiforme avec hyperepidermotrophic. Ann Dermatol Syphil (Paris) 1902;3: $1-31$.

2 Simpson JR. Congenital ichthyosiform erythroderma. Trans St John's Hosp Dermatol Soc 1964:50:1-31.

${ }^{3}$ Wells RS, Kerr CB. Genetic classification of ichthyosis. Arch Dermatol 1965:92:1-5.

${ }^{4}$ Williams ML. The ichthyoses-pathogenesis and prenatal diagnosis: a review of recent advances. Pediatr Dermatol 1983;1:1-24

5 Weibel ER. Schnyder UW. Zur ultrastruktur und histochemie der granulosen degeneration bei bulloser erythrodermie congenitale ichthyosiforme. Arch Klin Exp Dermatol 1966;233: 124-38.

- Ishibashi Y. Klingmuller G. Erythrodermia ichthyosiformis congenita bullosa Brocq. Uber die sogenannte granulose degencration. Arch Klin Exp Dermatol 1968:233:124-38.

${ }^{7}$ Golbus MS, Sagebiel RW, Filly RA. Gindhart TD. Hall JG. Prenatal diagnosis of congenital bullous ichthyosiform erythroderma (epidermolytic hyperkeratosis) by fetal skin biopsy. N Engl J Med 1980:302:93-5.

* Anton-Lamprecht I. Prenatal diagnosis of genetic disorders of the skin by means of electron microscopy. Hum Genet 1981:59:392-405.

${ }^{4}$ Holbrook KA. Dale BA. Sybert VP. Sagebicl RW. Epidermolytic hyperkeratosis: ultrastructure and biochemistry of skin and amniotic fluid cells from two affected fetuses and a newborn infant. J Invest Dermatol 1938:80:222-7.

1" Rodeck CH, Eady RAJ, Gosden CM. Prenatal diagnosis of epidermolysis bullosa letalis. Lancet 1980;: i:949-52.
"Rodeck $\mathrm{CH}$. Nicolaides KH. Fetoscopy and fetal tissue sampling. Br Med Bull 1983;39:332-7.

12 Eady RAJ, Rodeck CH. Prenatal diagnosis of disorders of the skin. In: Rodeck CH. Nicolaides KH. eds. Proceedings of the IIth Study Group of the Roval College of Obstetricians and Gynaecologists. London: Royal College of Obstetricians and Gynaccologists, 1984:147-58.

13 Eady RAJ, Gunner DB. Tidman MJ. Nicolaides KH. Rodeck $\mathrm{CH}$. Rapid processing of fetal skin for prenatal diagnosis by light and electron microscopy. J Clin Pathol 1984:37:633-8.

it Karnovsky MJ. A formaldehyde-glutaraldehyde fixative of high osmolality for use in electron microscopy. J Cell Biol 1965:27:137-8A.

15 Gosden CM. Brock DJH. Morphology of rapidly adhering amniotic fluid cells as an aid to the diagnosis of neural tube defects. Lancet 1977;i:919-22.

16 Gosden CM. Brock DJH. Combined use of alphafetoprotein and amniotic fluid cell morphology in carly prenatal diagnosis of fetal abnormalities. J Med Genet 1978:15:262-70.

${ }^{17}$ Gosden CM, Buckton K. Fetheringham Z, Brock DJH. Prenatal karyotyping and maternal serum alphafetoprotein screening. Br Med J 1981:282:255-8.

${ }^{18}$ Holbrook KA. Human epidermal embryogenesis. Int $J$ Der matol 1979:18:329-56.

${ }^{19}$ Hoyes AD. Ultrastructure of the cells of the amniotic fluid. $J$ Obstet Gynaecol 1968:75:164-71.

20) Nieland ML. Parmley TH. Woodruff JD. Ultrastructural observations on amniotic fluid cells. Am J Obstet Gynecol 1970;108: 1030-42.

21 Eady RAJ. Gunner DB, Leigh IM. Detection of tonofilament clumping in epidermal and amniotic fluid cells enables prenatal diagnosis of bullous ichthyosiform erythroderma (BIE). J Cutan Pathol 1983:11:212.

22 Gosden CM. Amniotic fluid cell types and culture. Br Med Bull 1983:39:348-54.

${ }^{23}$ Frost P. Weinstein GD. Van Scott EJ. The ichthyosiform dermatoses. II. Autoradiographic studies of epidermal prolifcration. J Invest Dermatol 1966:47:561-7.

${ }^{24}$ Elias A. Mazur M. Sabbagha R. Esterly NB. Simpson JL. Prenatal diagnosis of harlequin ichthyosis. Clin Genet 1980:17:275-80.

${ }^{25}$ Kousseff BG, Matsouka LY. Steen KS, Hobbins JC. Mahoney MJ. Hashimoto K. Prenatal diagnosis of Sjögren-Larsson syndrome. J Pediatr 1982:101:998-1001.

${ }^{26}$ Hahnel R. Hahnel E. Wysocki SJ. Wilkinson SP. Hockey A. Prenatal diagnosis of X-linked ichthyosis. Clin Chim Acta 1982;120:143-52.

Correspondence and requests for reprints to $\mathrm{Dr}$ R A J Eady, Department of Electron Microscopy and Cell Pathology, Institute of Dermatology, Homerton Grove, London E9 6BX. 